\title{
PREVALENCE OF AUTOANTIBODIES REVEALS A PREDOMINANT SMA AND ANCA-PR3/MPO PATTERN IN HIV INFECTION AND SMA IN HAV-INFECTED CHILDREN
}

\author{
Luz M. Navarta, Carlos A. Espul and Nelson Acosta-Rivero \\ Laboratorio de Virología, Hospital Central de Mendoza, Mendoza, Argentina
}

Received 2014-08-08; Revised 2014-09-10; Accepted 2014-09-12

\begin{abstract}
Hepatitis A Virus (HAV) and Human Immunodeficiency Virus (HIV) have been associated with development of autoantibodies and autoimmune manifestations in children. Autoimmune Hepatitis (AIH) is particularly aggressive in children/adolescents with a more severe outcome. Thus, studying the mechanisms of virus-related autoimmune disorders in children is a relevant topic of research. We aimed to study the prevalence of autoantibodies in plasma of children infected with either HAV or HIV comparing to healthy children. The relationship between the presence of autoantibodies and biochemical markers of hepatic damage was also investigated. Detection of autoantibodies (SMA) was associated with HAV infection with a prevalence of 35\%. Similar levels of hepatic enzymes were observed in sera of $\mathrm{HAV}$-infected patients with reactivity against autoantigens as compared to those without autoantibodies. On the other hand, HIV infection showed broader autoantibodies reactivities than HAV-infected patients and was associated with SMA (18\%), ANCA (20\%), ANCA-PR3 (15\%) and ANCA-MPO (13\%). Moreover, either RF or ANA was detected in $8 \%$ of HIV-infected children. Prevalence of autoantibodies was not associated with either gender or age of infected children. A high prevalence of SMA was observed in HAV- and HIV-infected patients. As HAV and SMA may persit in some patients and AIH can develop in susceptible children, it is recommended a follow up of virus infected patients. Since ANCA-PR3 and ANCA-MPO have been shown to be pathogenic, proinflammatory and associated with symptomatic HIV infection, further studies are required to determine the role of these autoantibodies in the pathogenesis associated with viral infection in children.
\end{abstract}

Keywords: HAVM, HIV, SMA, ANCA, Children

\section{INTRODUCTION}

Hepatitis A Virus (HAV) and Human Immunodeficiency Virus (HIV) infections have been recognized with the ability of breaking tolerance to selfantigens, promoting self-reactivity and autoimmune diseases (Dan and Yaniv, 1990; Roessler, 2007). Children are susceptible to infection with HAV and HIV and to develop autoimmune diseases (Huppertz et al., 1995; Skoog et al., 2002; Adebajo, 1997). However, little is known about the pathogenesis of these viral infections in promoting self-reactivity and development of autoimmune manifestations in paediatric individuals (Moon et al., 2009; Argüello et al., 2012). Some of the extrahepatic manifestations and autoimmune diseases associated with HAV infection consist of: Cholestatic hepatitis, cutaneous vasculitis (Dan and Yaniv, 1990), cryoglobulinemia (Ilan et al., 1990), several neurologic syndromes (Tabor, 1987), lupus (Segev et al., 2001), thrombocytopenic purpura (Cohen et al., 1993) and Corresponding Authors: Luz M. Navarta and Nelson Acosta-Rivero, Laboratorio de Virología, Hospital Central de Mendoza, Mendoza, Argentina. Email: lmnavarta@hotmail.com; n.acostarivero@latinmail.com 
Autoimmune Hepatitis (AIH) (Muñoz Bertrán et al., 2002). Autoimmune and systemic diseases that have been described in HIV-infected patients (ZandmanGoddard and Shoenfeld, 2002) include: Vasculitis, immune cytopenias, rheumatic diseases, lupus, sarcoidosis, thyroid diseases, hepatic diseases and antiphospholipid syndrome (Iordache et al., 2014). Several autoantibodies have been associated with these pathologies including Antinuclear (ANA), Antimitochondrial (AMA), Antismooth muscle (SMA), Antiparietal Cells (APC), anti-Liver-KidneyMicrosomal (LKM), anti-double strand DNA (DNAds), anti-Tyro Globulin (ATG), Rheumatoid Factor (RF) and Anti-Neutrophil Cytoplasmic (ANCA) antibodies (Moon et al., 2009; Liberal et al., 2013).

HAV has been suggested as a factor contributing to development AIH in both adults and individuals that are susceptible for autoimmune diseases (Muñoz Bertrán et al., 2002). AIH is particularly aggressive in children/adolescents with a more severe outcome (Pando et al., 1999; Floreani et al., 2013). In addition, AIH Type 1 is the major cause of chronic liver disease in Argentinian children (Cuarterolo et al., 1995). Moreover, the presence of autoantibodies has been correlated positively with the severity of hepatic lesions in AIH type-1 (Matsuo et al., 2000). On the other hand, a small number of studies have reported the presence of autoantibodies and a lower prevalence of autoimmune diseases in HIV-infected children as compared to adults (Argüello et al., 2012). Thus, studying the mechanisms of virus-related autoimmune disorders in children is a relevant topic of research.

Detection of autoantibodies is an important criterion for diagnosis and classification of extrahepatic manifestations associated with HAV infection as well as type 1 and 2 AIH (Liberal et al., 2013). Besides, it is also relevant to decide optimal treatment options against
HAV and HIV. Furthermore, studying the prevalence of autoantibodies in sera of patients with these viral infections is relevant to elucidate the mechanisms of viral infection-related autoimmune manifestations induction. Therefore, the main objective of this study was to study the prevalence of autoantibodies in sera of patients infected with either HAV or HIV as compared to healthy individuals. In addition, the relationship between the presence of autoantibodies and biochemical markers of hepatic damage was investigated.

\section{MATERIALS AND METHODS}

\subsection{Patients}

Data of patients studied in this study are shown in Table 1 to 5. Control group was negative for: HAV, Hepatitis B Virus (HBV), Hepatitis C Virus (HCV), HIV, Human T-Lymphotropic Virus 1 (HTLV-1), chagas disease and toxoplasmosis. Written informed consent was obtained from the parents of each patient and the study was approved by the Ethics Committee of Medical Research from the Hospital Central in accordance with the 1975 Declaration of Helsinki.

Either HAV or HIV children coinfected with HBV and $\mathrm{HCV}$ were excluded from this study. In addition, children with previous hepatic diseases (including $\mathrm{AIH}$, cholestasis or infectious hepatitis) were excluded from this study.

\subsection{Autoantibodies}

Autoantibodies reactive for ANA, AMA, SMA, APC, LKM, DNAds and ANCA were assayed by indirect immunofluorecense. ANCA proteinase-3 (ANCA-PR3) and ANCA myeloperoxidase (ANCA-MPO) were assayed by ELISA (Binding site. UK).

TGA and RF were assayed by particle aglutination.

Table 1. Autoantibodies (auto-Abs) prevalence in HAV-infected patients

\begin{tabular}{|c|c|c|c|c|}
\hline Auto-Abs & $\begin{array}{l}\text { Patients auto-abs+l } \\
\text { total patients } \mathrm{HCV}+(\%)\end{array}$ & Auto-abs titers (Range) & $\begin{array}{l}\text { Controls auto-abs+l } \\
\text { total controls }(\%)\end{array}$ & $\mathrm{P}$ \\
\hline$\overline{\mathrm{RF}}$ & $1 / 54(2 \%)$ & $1: 40$ & $0 / 44(0 \%)$ & 1 \\
\hline SMA & $19 / 54(35 \%)$ & $1: 50(1: 20-1: 160)$ & $0 / 44(0 \%)$ & $<0.0001$ \\
\hline ANCA & $0 / 54(0 \%)$ & N/A & $0 / 44(0 \%)$ & N/A \\
\hline ANA & $0 / 54(0 \%)$ & N/A & $0 / 44(0 \%)$ & N/A \\
\hline ANTI DNA dc & $0 / 54(0 \%)$ & N/A & $0 / 44(0 \%)$ & N/A \\
\hline AMA & $0 / 54(0 \%)$ & N/A & $0 / 44(0 \%)$ & N/A \\
\hline ATG & $0 / 54(0 \%)$ & N/A & $0 / 44(0 \%)$ & N/A \\
\hline Anti-LKM & $0 / 54(0 \%)$ & N/A & $0 / 44(0 \%)$ & N/A \\
\hline APC & $1 / 54(2 \%)$ & $1: 40$ & $0 / 44(0 \%)$ & 1 \\
\hline
\end{tabular}

P: Exact Fisher Test. N/A: Not Applicable 


\subsection{Liver Function Serum Enzymes}

Aspartate Transaminase/Glutamic Oxaloacetic Transaminase (AST/SGOT) and Alanine Transaminase/Glutamic-Pyruvic Transaminase (ALT/SGPT) were assayed using conventional methods.

\subsection{Statistics}

Graph Prism 5.0 statistical software package was used for data analysis. Data was expressed as Mean \pm $\mathrm{SD}$ for quantitative measures and both number and percentage for categorized data. Comparison between two independent means for parametric data was done using student test. Comparison between two independent groups for non-parametric data was done using Mann Whitney test. The fisher exact test used to study the association between 2 variables, or comparison between 2 independent groups as regards the categorized data. The probability of error at 0.05 was considered significant.

\section{RESULTS}

Presence of at least one autoantibody was detected in $19(35 \%)$ out of 54 samples of HAV-infected children $(\mathrm{p}<0.0001$, Fisher exact test) (Table 1 and 3). In addition, concomitant detection of more than one antibody showed a prevalence of $3.7 \%$. HAV infection was associated with SMA $(35 \%, \mathrm{p}<0.0001$ fisher exact test) (Table 1 and 3). Either RF or APC reactivities was observed in one patient. Moreover, no reactivities were detected for ANA, AMA, TGA,
LKM, DNAds and ANCA. Prevalence of autoantibodies (SMA), on the other hand, was not associated with either gender or age of HAV-infected children (Table 6). Furthermore, levels of biochemical markers of liver damage (AST and ALT) showed no difference between samples of HAVinfected patients reactive to autoantibodies and those no-reactive (Table 7).

It is interesting to note that HIV-infected children showed broader autoantibodies reactivities than HAVinfected patients. The presence of autoantibodies was observed in 18 out of 39 children (46\%) and was not associated with either gender or age of HIV-infected children (Table 2, 4 and 8). Concomitant detection of more than one antibody was observed in $3 \mathrm{HIV}$ infected children (7.7\%). HIV infection was associated with SMA $(18 \%, \mathrm{p}=0.0037)$ and ANCA $(20 \%, p=0.0016)$ (Table 2 and 4). Notably, prevalence of both ANCA-PR3 $(15 \%, \mathrm{p}=0.0086)$ and ANCA-MPO $(13 \%, \mathrm{p}=0.0198)$ was associated with HIV-infection. Interestingly, a mixed pattern of ANCA-PR3 and ANCA-MPO was observed in 3 patients (8\%) (Table 4). Moreover, either RF or ANA was detected in $8 \%$ of HIV-infected children. Prevalence of SMA, on the other hand, was not associated with either gender $(p=0.3863)$ or age $(p=$ 1) of infected children. In addition, prevalence of ANCA was neither associated with gender $(\mathrm{p}=1)$ nor age $(\mathrm{p}=0.6857)$ of patients. No reactivities were detected for TGA, APC, AMA, LKM and DNAds. Finally, similar SMA titers were observed in HAVand HIV-infected children ( $\mathrm{p}=0.4119$, Mann Whitney test)

(Fig.

Table 2. Autoantibodies (auto-Abs) prevalence in chronically HIV-infected patients

\begin{tabular}{lllll}
\hline & $\begin{array}{l}\text { HIV+ auto-abs+ } \\
\text { patients/total HIV+ } \\
\text { putients }(\%)\end{array}$ & Auto-abs titles (range) & $\begin{array}{l}\text { Control individuals } \\
\text { auto-abs+/total control } \\
\text { individuals individuos controls (\%) }\end{array}$ & P \\
\hline RF & $3 / 39(8 \%)$ & $1: 67(1: 40-1: 80)$ & $0 / 44(0 \%)$ & 0,099 \\
SMA & $7 / 39(18 \%)$ & $1: 54(1: 20-1: 80)$ & $0 / 44(0 \%)$ & 0,0037 \\
ANCA total & $8 / 39(20 \%)$ & N/A & $0 / 44(0 \%)$ & 0,0016 \\
ANCA MPO* & $5 / 39(13 \%)$ & $15,6^{*}(14,5-16,4)$ & $0 / 44(0 \%)$ & 0,0198 \\
ANCA PR3* & $6 / 39(15 \%)$ & $7,9^{*}(5,1-15)$ & $0 / 44(0 \%)$ & 0,0086 \\
ANA & $3 / 39(8 \%)$ & $1: 73(1: 20-1: 160)$ & $0 / 44(0 \%)$ & 0,099 \\
TGA & $0 / 39(0 \%)$ & N/A- & $0 / 44(0 \%)$ & N/A \\
APC & $0 / 39(0 \%)$ & N/A & $0 / 44(0 \%)$ & N/A \\
Anti DNAdc & $0 / 39(0 \%)$ & N/A & $0 / 44(0 \%)$ & N/A \\
AMA & $0 / 39(0 \%)$ & N/A & $0 / 44(0 \%)$ & N/A \\
Anti LKM & $0 / 39(0 \%)$ & N/A & $0 / 44(0 \%)$ & N/A \\
\hline P: Exact Fis & & &
\end{tabular}

P: Exact Fisher Test. * ELISA Units. N/A: Not Applicable 
Luz M. Navarta et al. / American Journal of Immunology 10 (3): 144-155, 2014

Table 3. Demographic and clinical features in HAV-infected children

\begin{tabular}{|c|c|c|c|c|c|}
\hline Patient & Age & Gender & AST & ALT & Auto-Abs (Titers) \\
\hline 1 & 9 & $\mathrm{M}$ & 136 & 424 & ND \\
\hline 2 & 8 & $\mathrm{~F}$ & 512 & 879 & SMA (40) \\
\hline 3 & 11 & M & 1145 & 1551 & ND \\
\hline 4 & 3 & $\mathrm{~F}$ & 831 & 487 & ND \\
\hline 5 & 5 & $\mathrm{~F}$ & 199 & 371 & SMA (40) \\
\hline 6 & 4 & M & 750 & 1280 & ND \\
\hline 7 & 12 & M & 1219 & 1318 & SMA 40()/APC (40) \\
\hline 8 & 15 & M & 841 & 967 & ND \\
\hline 9 & 10 & M & 279 & 315 & ND \\
\hline 10 & 2 & $\mathrm{~F}$ & 522 & 359 & ND \\
\hline 11 & 10 & M & 175 & 230 & SMA (20) \\
\hline 12 & 11 & M & 624 & 917 & SMA (40) \\
\hline 13 & 7 & M & 716 & 881 & SMA (80) \\
\hline 14 & 9 & M & 1679 & 928 & ND \\
\hline 15 & 6 & $\mathrm{~F}$ & 743 & 832 & SMA (40) \\
\hline 16 & 4 & $\mathrm{~F}$ & 675 & 734 & SMA (40) \\
\hline 17 & 3 & M & 452 & 631 & ND \\
\hline 18 & 5 & $\mathrm{~F}$ & 317 & 570 & ND \\
\hline 19 & 7 & M & 839 & 1027 & ND \\
\hline 20 & 14 & M & 912 & 728 & ND \\
\hline 21 & 10 & M & 360 & 219 & ND \\
\hline 22 & 7 & $\mathrm{~F}$ & 570 & 846 & SMA (40) \\
\hline 23 & 6 & $\mathrm{~F}$ & 615 & 1021 & ND \\
\hline 24 & 9 & M & 522 & 783 & SMA (160) \\
\hline 25 & 3 & $\mathrm{~F}$ & 411 & 525 & ND \\
\hline 26 & 12 & $\mathrm{~F}$ & 328 & 697 & ND \\
\hline 27 & 9 & $\mathrm{~F}$ & 563 & 890 & ND \\
\hline 28 & 8 & M & 987 & 1203 & SMA (40) \\
\hline 29 & 10 & M & 182 & 415 & ND \\
\hline 30 & 6 & M & 335 & 572 & ND \\
\hline 31 & 7 & M & 714 & 1235 & SMA (40) \\
\hline 32 & 2 & $\mathrm{~F}$ & 618 & 756 & SMA (40) \\
\hline 33 & 5 & $\mathrm{~F}$ & 902 & 1340 & ND \\
\hline 34 & 6 & M & 240 & 391 & ND \\
\hline 35 & 15 & $\mathrm{~F}$ & 265 & 344 & SMA (40) \\
\hline 36 & 7 & $\mathrm{~F}$ & 554 & 785 & SMA (40) \\
\hline 37 & 5 & M & 297 & 320 & ND \\
\hline 38 & 4 & $\mathrm{~F}$ & 976 & 1013 & ND \\
\hline 39 & 3 & M & 932 & 865 & ND \\
\hline 40 & 7 & M & 136 & 289 & ND \\
\hline 41 & 10 & $\mathrm{~F}$ & 374 & 445 & ND \\
\hline 42 & 9 & M & 790 & 966 & ND \\
\hline 43 & 11 & $\mathrm{~F}$ & 825 & 560 & ND \\
\hline 44 & 7 & $\mathrm{~F}$ & 841 & 1024 & ND \\
\hline 45 & 4 & M & 417 & 685 & SMA (40) \\
\hline 46 & 14 & M & 392 & 740 & SMA (40) \\
\hline 47 & 13 & $\mathrm{~F}$ & 730 & 1282 & ND \\
\hline 48 & 5 & $\mathrm{~F}$ & 649 & 803 & ND \\
\hline 49 & 6 & M & 1072 & 905 & ND \\
\hline 50 & 13 & $\mathrm{~F}$ & 568 & 751 & ND \\
\hline 51 & 4 & $\mathrm{~F}$ & 297 & 376 & ND \\
\hline 52 & 9 & $\mathrm{~F}$ & 453 & 842 & ND \\
\hline 53 & 6 & M & 692 & 933 & SMA (40) \\
\hline 54 & 13 & M & 929 & 1050 & SMA (80)/RF (40) \\
\hline
\end{tabular}

Auto-Abs: Autoantibodies. ND: No detection 
Luz M. Navarta et al. / American Journal of Immunology 10 (3): 144-155, 2014

Table 4. Demographic and clinical and virological features in HIV-infected children

\begin{tabular}{|c|c|c|c|}
\hline Patient & Age & Gender & Auto-abs (titers) \\
\hline 1 & 0.66 & $\mathrm{M}$ & ND \\
\hline 2 & 1.16 & M & ND \\
\hline 3 & 2.25 & $\mathrm{~F}$ & ANCAPR3 (6.7U)/M (16U) \\
\hline 4 & 5.00 & M & ND \\
\hline 5 & 3.00 & $\mathrm{~F}$ & ND \\
\hline 6 & 7.00 & $\mathrm{~F}$ & ANCAM (16.4U) \\
\hline 7 & 5.00 & M & ND \\
\hline 8 & 4.00 & $\mathrm{~F}$ & SMA (80)/RF (80) \\
\hline 9 & 6.00 & $\mathrm{~F}$ & ND \\
\hline 10 & 2.00 & $\mathrm{~F}$ & ND \\
\hline 11 & 8.00 & M & ND \\
\hline 12 & 7.00 & M & ANA (40) \\
\hline 13 & 6.00 & $\mathrm{~F}$ & ND \\
\hline 14 & 2.00 & $\mathrm{~F}$ & ND \\
\hline 15 & 3.00 & M & ANCAPR3 (5.1U) \\
\hline 16 & 6.00 & $\mathrm{~F}$ & SMA (20) \\
\hline 17 & 3.00 & $\mathrm{~F}$ & SMA (40) \\
\hline 18 & 4.00 & $\mathrm{~F}$ & ND \\
\hline 19 & 6.00 & $\mathrm{~F}$ & ANA (40)/RF (20) \\
\hline 20 & 7.00 & $\mathrm{~F}$ & SMA $(80)$ \\
\hline 21 & 0.25 & $\mathrm{~F}$ & ND \\
\hline 22 & 3.00 & $\mathrm{~F}$ & ND \\
\hline 23 & 1.00 & $\mathrm{~F}$ & ND \\
\hline 24 & 5.00 & M & ANCAPR3 (7.4U)/M (15.1U) \\
\hline 25 & 1.50 & M & ND \\
\hline 26 & 6.00 & $\mathrm{~F}$ & ANCAPR3 (15U)/M (16.2U) \\
\hline 27 & 2.00 & M & ND \\
\hline 28 & 6.00 & $\mathrm{~F}$ & ND \\
\hline 29 & 5.00 & M & ANCAPR3 (8.2U) \\
\hline 30 & 2.00 & M & ANA (160) \\
\hline 31 & 4.00 & M & ND \\
\hline 32 & 1.66 & $\mathrm{~F}$ & $\operatorname{ANCAM}(14.5 \mathrm{U}) / \mathrm{RF}(80)$ \\
\hline 33 & 3.00 & $\mathrm{~F}$ & ANCAPR3 \\
\hline 34 & 2.00 & $\mathrm{~F}$ & ND \\
\hline 35 & 1.50 & $\mathrm{~F}$ & ND \\
\hline 36 & 0.75 & $\mathrm{~F}$ & SMA (40) \\
\hline 37 & 3.00 & $\mathrm{~F}$ & ND \\
\hline 38 & 7.00 & M & SMA (80) \\
\hline 39 & 3.00 & $\mathrm{~F}$ & SMA (40) \\
\hline
\end{tabular}

Auto-Abs: Autoantibodies. ND: No detection

Table 5. Demographic data of patients include in this study

\begin{tabular}{llll}
\hline Samples & Number of children & Average age (range) & Gender (F/M) \\
\hline Children HAV+ & 54 & $7,7(2-15)$ & $24 / 30$ \\
Children HIV+ & 39 & $3,7(0,25-15)$ & $25 / 14$ \\
Children controls & 44 & $7,3(0,16-15)$ & $19 / 25$ \\
\hline
\end{tabular}

Table 6. Prevalence of autoantibodies in HAV-infected (HAV+) patients according to gender and age

\begin{tabular}{lllll}
\hline $\begin{array}{l}\text { Prevalence of SMA } \\
\text { in HAV+ patients (total) }\end{array}$ & $\begin{array}{c}\text { Gender female } \\
(\mathrm{n}=24) \mathrm{p}^{*}(\%)\end{array}$ & $\begin{array}{c}\text { Gender male } \\
(\mathrm{n}=30)(\%)\end{array}$ & $\begin{array}{c}\text { Age }<10 \text { years } \\
\text { old }(\mathrm{n}=37) \mathrm{p}^{*}(\%)\end{array}$ & $\begin{array}{c}\text { Age }>/=10 \text { years old } \\
(\mathrm{n}=17)(\%)\end{array}$ \\
\hline Positivos $(\mathrm{n}=19)$ & $8(33.33) \mathrm{a}$ & $11(36.66) \mathrm{a}$ & $13(35.13) \mathrm{b}$ & $6(35.29) \mathrm{b}$ \\
Negativos $(\mathrm{n}=35)$ & $16(66.66)$ & $19(63.33)$ & $24(64.86)$ & $11(64.70)$ \\
\hline
\end{tabular}

Gender: $* \mathrm{p}=1$, Age: $* \mathrm{p}=1$, Fisher exact test 
Table 7. Enzyme levels (AST and ALT) in serum of HAV-infected patients

\begin{tabular}{llll}
\hline Auto-abs & SMA + & SMA- & P \\
\hline AST $^{*}$ & $606.5 \pm(263.5)$ & $616.5 \pm(339.2)$ & 0.9111 \\
ALT $^{*}$ & $816.9 \pm(285.3)$ & $736.5 \pm(337.6)$ & 0.3824 \\
\hline
\end{tabular}

*: Average title UI/L (Standard deviation), p: Student $t$ test

Table 8. Prevalence of autoantibodies (auto-abs) in HIV-infected patients according to gender and age

\begin{tabular}{lllll}
$\begin{array}{l}\text { Prevalence of auto-abs } \\
\text { in HIV+ patients (total) }\end{array}$ & $\begin{array}{c}\text { Genre female } \\
(\mathrm{n}=25) \mathrm{p}^{*}(\%)\end{array}$ & $\begin{array}{c}\text { Genre male } \\
(\mathrm{n}=14)(\%)\end{array}$ & $\begin{array}{l}\text { Age }<5 \text { years old } \\
(\mathrm{n}=24) \mathrm{p}^{*}(\%)\end{array}$ & $\begin{array}{l}\text { Age }>/=5 \text { years } \\
\text { old }(\mathrm{n}=15)(\%)\end{array}$ \\
\hline Positivos $(\mathrm{n}=18)$ & $12(48) \mathrm{a}$ & $6(42.85)$ & $9(37.5)$ & $9(60)$ \\
Negativos $(\mathrm{n}=21)$ & $13(52)$ & $8(57.14)$ & $15(62.5)$ & $6(40)$ \\
\hline
\end{tabular}

Gender: *p $=1$, Age: $* \mathrm{p}=0.2028$, fisher exact test

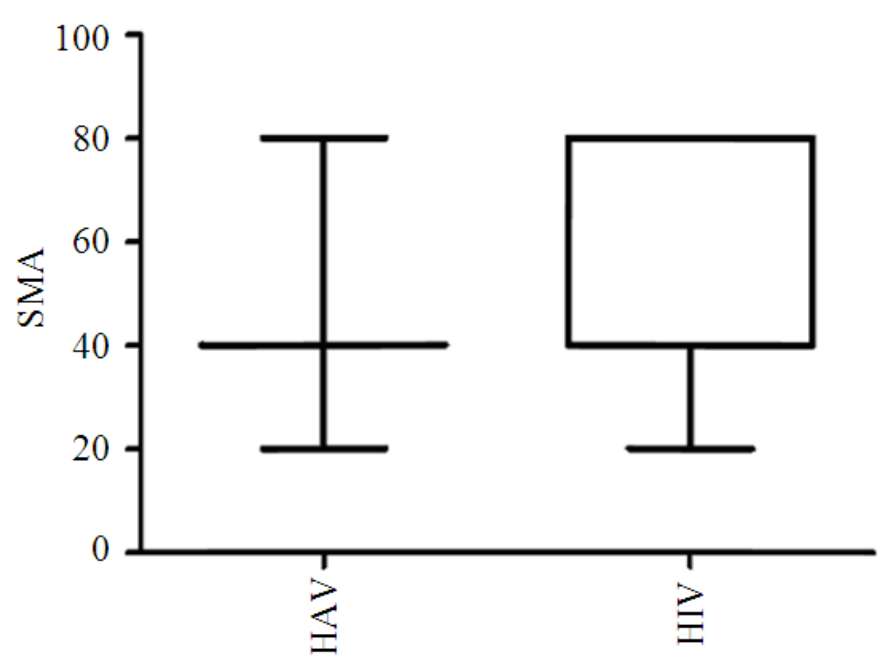

Fig. 1. SMA titers in HAV-and HIV-infected children ( $p=0.4119$, Mann Whitney test)

\section{DISCUSSION}

HAV infection is a common cause of acute hepatitis worldwide (Moon et al., 2009). In Argentina, HAV occurrence has been reported to vary from low to high endemicity in different regions (Gonzalez et al., 1997). Although HAV is mostly a self-limiting disease, prolonged infection has been reported in both adults and children (Vento et al., 1991; Fainboim et al., 2001; Elfaramawy et al., 2010). HAV infection has been associated with development of extrahepatic manifestations and autoimmune diseases that are related with the production of autoantibodies in susceptible individuals (Dan and Yaniv, 1990; Huppertz et al., 1995; Skoog et al., 2002; Moon et al., 2009; Ilan et al., 1990; Tabor, 1987; Segev et al., 2001; Cohen et al., 1993; Muñoz Bertrán et al., 2002; Fainboim et al., 2001; Elfaramawy et al., 2010; Singh et al., 2007). Transient increased levels of autoantibodies have been documented in acute HAV infection and after vaccination (Fainboim et al., 2001; Karali et al., 2011; Gutierrez et al., 1996; Vento et al., 1988; Holborow et al., 1971; Seok et al., 2011). However, persistent autoantibodies have been detected in prolonged HAV infection in children (Fainboim et al., 2001; Elfaramawy et al., 2010). Particularly, SMA, ANA and antiasialoglycoprotein receptor antibodies have been associated with HAV infection (Moon et al., 2009; Fainboim et al., 2001; Elfaramawy et al., 2010; Karali et al., 2011; Gutierrez et al., 1996; Vento et al., 1988; Holborow et al., 1971; Seok et al., 2011).

Several mechanisms have been proposed to explain HAV-related induction of autoantibodies and autoimmune diseases including impaired function of regulatory $\mathrm{T}$ cells. HAV have been suggested to impair CD4+/CD25+ $\mathrm{T}$ regulatory lymphocytes in self-limited infection (Perrella et al., 2008). Interestingly, it has been shown that interaction of HAV with its Cellular Receptor 
1 (HAVCR1) inhibited regulatory $\mathrm{T}$ cell functions and reduced production of Transforming Growth Factor- $\beta$ (TGF- $\beta$ ) and IL-10 (Manangeeswaran et al., 2012). Moreover, individuals with a defect in suppressorinducer $\mathrm{T}$ lymphocytes (that control immune responses to the asialoglycoprotein receptor) have been suggested to develop AIH type 1 after HAV infection (Vento et al., 1991). In addition, antibodydependent citotoxicity has been involved in $\mathrm{AIH}$ (Vergani and Mieli-Vergani, 2008).

In this study, high prevalence of SMA (35\%) was associated with $\mathrm{HAV}+$ patients. This is in agreement with previous reports showing similar prevalence of SMA in HAV+ children (Fainboim et al., 2001; Elfaramawy et al., 2010). Although transient SMA reactivities have been observed in self-limited HAV infection, persistence of SMA has been associated with proctacted forms of paediatric infection (Fainboim et al., 2001; Elfaramawy et al., 2010). Interestingly, HLA DRB1*1301 haplotype has been associated with a higher susceptibility to develop prolonged HAV infection in children (Fainboim et al., 2001). Notably, HLA DRB 1*13 haplotype has shown a strong association with paediatric type $1 \mathrm{AIH}$ in high endemicity regions for HAV infection (Elfaramawy et al., 2010; Bittencourt et al., 2008; Fainboim et al., 1994; Bittencourt et al., 1999). In addition, prevalence of AIH type 1 with a pattern SMA/ANA reactivities is higher than AIH type 2 (LKM-1 reactivity) in children (Vergani and Mieli-Vergani, 2008). On the other hand, HAV vaccination has been associated with development of autoantibodies and rarely with autoimme hepatitis (Karali et al., 2011; Berry and Smith-Laing, 2007; Perumalswami et al., 2009). These experimental evidences suggest that AIH type 1 may develop after prolonged HAV infection in susceptible individuals (Huppertz et al., 1995; Skoog et al., 2002; Vento et al., 1991; Singh et al., 2007). Patients in this study were studied in the acute phase of infection and not at later times after infection. So, neither the prolonged nature of detected autoantibodies nor its association with viral presistance could be assessed. As both HAV and autoantibodies (SMA) may persit in some patients and AIH can develop in susceptible children, a follow up of virus infected patients is important.

Some studies have shown SMA associated with biochemical and histological features of disease activity in adult HAV infection and AIH (Dan and Yaniv, 1990; Couto et al., 2014). However, in the current study SMA was not related to the levels of biochemical markers of liver damage in infected children. Different experimental conditions and susceptibilities between children and adults may explain these discrepancies. In fact, different gene susceptibilities have been shown in children with AIH (associated with HLA DRB $1 * 13$ haplotype) as compared to adults (associated with HLA-DRB1*0405 haplotype) (Pando et al., 1999). Different autoantibody profiles have also been reported, with higher prevalence of SMA in paediatric AIH and of ANA in adult AIH (Pando et al., 1999). In addition, HLA-DRB1*12 haplotype has been associated with paediatric HAVrelated AIH type 1 (Elfaramawy et al., 2010).

On the other hand, HIV-infected individuals with various levels of immunological control have been associated with different autoimmune diseases (Iordache et al., 2014). However, few studies have reported the presence of autoimmune diseases in HIVinfected children. These studies have shown a lower prevalence of autoimmune diseases in children as compared to adults (Adebajo, 1997; Nguyen and Reveille, 2009; Schuval et al., 2001; Martínez-Rojano et al., 2001; Rodríguez-Mahou et al., 1994; Jarvis et al., 1993; Rodriguez et al., 1993; González et al., 1998; Stricker et al., 1998; Eley et al., 1999). Long term HIV infection leading to chronic activation and exhaustion of the host immune system and increased expression of autoantigens has been proposed to promote development of autoimmune diseases (Gaddi et al., 2000). Several autoantibodies have been associated with HIV infection in children including ANA, SMA, DNAds and RF. It has been suggested that polyclonal $\mathrm{B}$ cell activation, increased levels of total immunoglubulins and dysfunction of CD4+ $\mathrm{T}$ regulatory cells contribute to development of autoantibodies in HIV-infected children in the absence of clinical autoimmune disease (Argüello et al., 2012; Rodriguez et al., 1993; González et al., 1998; Stricker et al., 1998; Eley et al., 1999). Interestingly, low absolute levels of CD4+FoxP3+T cells and enhanced frequencies of a subset of dysfunctional regulatory $\mathrm{T}$ cells (CD4+FoxP3+CD25- T cells) have been associated with a higher prevalence of autoantibodies and hypergammaglobulinaemia in HIV-infected children with severe immunosuppression (Argüello et al., 2012).

In this study, the presence of autoantibodies was associated with HIV infection $(46 \%)$. Prevalence of SMA (18\%), ANA and RF (8\%) in HIV-infected children is in agreement with previous reports 
(Argüello et al., 2012; Schuval et al., 2001; Rodríguez-Mahou et al., 1994; Jarvis et al., 1993). Interestingly, a previous study showed that SMA and RF were detected more frequently in HIV-infected children with low CD4+ T cell counts (Argüello et al., 2012). Detection of SMA in adult HIV-patients with low CD4+ $\mathrm{T}$ cells but not in patients with high CD4+ T cells has also been reported (Chretien et al., 2003). In the present study, CD4+ T cells levels were not assayed because of constrains in the samples available. Therefore, the relationship between autoantibodies reactivities and CD4+ T cells was not determined. Another limitation of this study was the lack of information on clinic manifestations. So, the relationship between autoantibodies reactivities and clinic manifestations could not be evaluated.

Interestingly, ANCA (20\%) was associated with HIV infection and ANCA-PR3/ANCA-MPO were observed in $6(15 \%)$ and $5(13 \%)$ patients, respectively. Moreover, a mixed pattern of ANCA-PR3 and ANCA-MPO were detected in 3 patients. ANCA have been associated with the pathogenesis of systemic vasculitis (Hu et al., 2009). Several experimental evidences support a pathogenic role for ANCA in the pathogenesis of ANCA-Associated Vasculitis (AAV). It has been shown that stimulation of neutrophils with pro-inflammatory cytokines (ex. TNF$\alpha$ ) induced translocation of ANCA antigens (PR3 and MPO) to the neutrophil surface. Binding of ANCA IgG to its antigens and $\mathrm{Fc}$ receptors activate neutrophils and release free oxygen radicals and various proteases contributing to pathogenesis in vasculitic lesions (Chen and Kallenberg, 2010). In addition, a crucial role for the alternative pathway of complement activation in ANCA-mediated neutrophil activation and AAV has been reported (Schreiber et al., 2009). Moreover, it has been observed in mice models that administration of anti-MPO induced leukocytes recruitment to sites affected in human ANCA-associated vasculitis such as kidney and lung (Nolan et al., 2008). It is interesting to note that PR3-specific Th17 cells have also been involved in ANCA-mediated autoimmune diseases pathogenesis (Abdulahad et al., 2008).

On the other hand, ANCA have been associated with symptomatic HIV infection in adults (prevalence 18\%-41.9\%) (Habegger de Sorrentino et al., 1997; Kamat et al., 2010; Cornely et al., 1999; Klaassen et al., 1992; Savige et al., 1994; Nikolova et al., 2002). Interestingly, ANCA have been positively correlated with pulmonary infection and Mycobacterium tuberculosis in HIV-infected patients (Habegger de Sorrentino et al., 1997). Nevertheless, prevalence of ANCA is low in asymptomatic HIV infection and ANCAassociated vasculitides are rare in infected individuals (Iordache et al., 2014; Habegger de Sorrentino et al., 1997; Cornely et al., 1999). In addition, most of reported studies have shown low prevalence of ANCA in children infected with HIV (Argüello et al., 2012). A recent study showed ANCA reactivities in 3 out of 15 (20\%) immunosupressed HIV-infected children (CD4+ T cells $<15 \%$ ) but no reactivity in children with no evidence of immunosuppression (CD4+ T cells $>25 \%$ ) (Argüello et al., 2012). Immunosupressed children showed low absolute levels of regulatory $\mathrm{T}$ cells and enhanced frequencies of a subset of dysfunctional regulatory $\mathrm{T}$ cells $(\mathrm{CD} 4+\mathrm{FoxP} 3+\mathrm{CD} 25-\mathrm{T}$ cells) in the absence of autoimmune disease. It is interesting to note that increased levels of the alternative complement pathway (complement activation fragments $\mathrm{C} 3 \mathrm{a}$ and $\mathrm{Bb}$ ), that is involved in ANCA pathogenesis, have been observed in HIV-infected children (Jarvis et al., 1993). Thus, ANCA (including ANCA-PR3, ANCAMPO and a mixed pattern ANCA-PR3/MPO in infected children) could contribute to pathogenesis of HIV-related diseases including autoimmunity.

HIV-infected children showed broader autoantibodies reactivities (SMA (18\%), ANCA (20\%), FR $(8 \%)$, ANA $(8 \%))$ than HAV-infected patients (SMA (35\%)). Higher reactivity against autoantigens in HIV-infected patients could be related with chronic infection, the viral ability to stimulate B lymphocytes persistently and virus antigenic mimicry with autoantigens (Zandman-Goddard and Shoenfeld, 2002). In addition, HAV mainly targets hepatocytes while HIV targets several immune cells directly affecting immune regulatory mechanisms (Cuarterolo et al., 1995).

\section{CONCLUSION}

In summary, detection of autoantibodies was associated with both HAV and HIV infection in children. HIV-infected patients showed broader reactivities for autoantibodies than HAV-infected children. HAV infection was associated with SMA while HIV infection was associated with SMA, ANCA-PR3 and ANCAMPO. Similar levels of biochemical markers of liver damage were observed in $\mathrm{HAV}$-infected patients with or without reactivity against autoantibodies. As HAV and SMA may persit in some patients and AIH can develop 
in susceptible children, it is recommended a follow up of virus infected patients. Children infected with HIV are an especially susceptible population. Since ANCA-PR3 and ANCA-MPO have been shown to be pathogenic, proinflammatory and associated with symptomatic HIV infection, further studies are required to determine the role of these autoantibodies in the pathogenesis associated with HIV infection in children.

\section{ACKNOWLEDGEMENT}

We would like to thanks Prof Virginia Rivero for her contribution to this study.

\section{REFERENCES}

Abdulahad, W.H., C.A. Stegeman, P.C. Limburg and C.G. Kallenberg, 2008. Skewed distribution of Th17 lymphocytes in patients with wegener's granulomatosis in remission. Arthritis Rheumatol., 58: 2196-2205. DOI: 10.1002/ART.23557

Adebajo, A.O., 1997. Rheumatic manifestations of infectious diseases in children. Current Opin. Rheumatol., 9: 68-74. PMID: 9110137.

Argüello, R.J., J. Balbaryski, G. Barboni, M. Candi and S. Laucella et al., 2012. Altered frequency and phenotype of CD4+ forkhead box protein 3+ T cells and its association with autoantibody production in human immunodeficiency virus-infected paediatric patients. Clin. Exp. Immunol., 168: 224-233. DOI: 10.1111/j.1365-2249.2012.04569.x

Berry, P.A. and G. Smith-Laing, 2007. Hepatitis a vaccine associated with autoimmune hepatitis. World J. Gastroenterol., 13: 2238-2239. DOI: 10.3748/WJG.V13.I15.2238

Bittencourt, P. L., A.Q. Farias, G. Porta, E.L.R. Cançado and F.J. Carrilho et al., 2008. Frequency of concurrent autoimmune disorders in patients with autoimmune hepatitis: Effect of age, gender and genetic background. J. Clin. Gastroenterol., 42: 300305. DOI: 10.1097/MCG.0B013E31802DBDFC

Bittencourt, P.L., A.C. Goldberg, E.L.R. Cançado, G. Porta and J. Kalil et al., 1999. Genetic heterogeneity in susceptibility to autoimmune hepatitis types 1 and 2susceptibility to AIH types 1 and 2. Am. J. Gastroenterol., 94: 1906-1913. DOI: 10.1111/J.1572-0241.1999.01229.X

Chen, M. and C.G.M. Kallenberg, 2010. Anca-associated vasculitides-advances in pathogenesis and treatment. Nature Rev. Rheumatol., 6: 653-64. DOI: 10.1038/NRRHEUM.2010.158
Chretien, P., J.C. Monier, F. Oksman, M. San Marco and J. Sibilia et al., 2003. Autoantibodies and human immunodeficiency viruses infection: A case-control study. Clin. Exp. Rheumatol., 21: 210-212. PMID: 12747276.

Cohen, O., D. Mevorach, Z. Ackerman and R. Oren, 1993. Thrombocytopenic purpura as a manifestation of acute hepatitis A. J. Clin. Gastroenterol., 17: 166-167. PMID: 8409322.

Cornely, O.A., S. Hauschild, C. Weise, E. Csernok and M. Schrappe et al., 1999. Seroprevalence and disease association of antineutrophil cytoplasmic autoantibodies and antigens in HIV infection. Infection, 27: 92-6. DOI: 10.1007/BF02560504

Couto, C.A., P.L. Bittencourt, G. Porta, C.P. AbrantesLemos and E.L. Cançado et al., 2014. Antismooth muscle and antiactin antibodies are indirect markers of histological and biochemical activity of autoimmune hepatitis. Hepatology, 59: 592-600. DOI: 10.1002/hep.26666

Cuarterolo, M., M. Ciocca and F. Álvarez, 1995. Hepatitis autoinmune en niños. Perspectivas actuales. Arch. Argent. Pediatr., 112 169-175. DOI: 10.5546/aap.2014.169

Dan, M. and M. Yaniv, 1990. Cholestatic hepatitis, cutaneous vasculitis and vascular deposits of immunoglobulin $\mathrm{M}$ and complement associated with hepatitis A virus infection. Am. J. Med., 89: 103107. DOI: 10.1016/0002-9343(90)90107-O

Eley, B.S., J. Hughes, S. Potgieter, M. Keraan and G.D. Hussey et al., 1999. Immunological manifestations of HIV-infected children. Annals Tropical Paediatr., 19: 3-7. DOI: $10.1080 / 02724939992572$

Elfaramawy, A.A., R.M. Elhossiny, A.A. Abbas and H.M. Aziz, 2010. HLA-DRB1 as a risk factor in children with autoimmune hepatitis and its relation to hepatitis A infection. Italian J. Pediatr., 36: 73-73. DOI: 10.1186/1824-7288-36-73

Fainboim, L., M.C.C. Velasco, C.Y. Marcos, M. Ciocca and M. Zelazko, 2001. Protracted, but not acute, hepatitis A virus infection is strongly associated with HLA-DRB $1 * 1301$, a marker for pediatric autoimmune hepatitis. Hepatology, 33: 1512-1517. DOI: 10.1053/jhep.2001.24562

Fainboim, L., Y. Marcos, M. Pando, M. Capucchio and M.L. Satz et al., 1994. Chronic active autoimmune hepatitis in children: Strong association with a particular HLA-DR6 (DRB1*1301) haplotype. Human Immunol., 41: 146-150. DOI: 10.1016/01988859(94)90008-6 
Floreani, A., R. Liberal, D. Vergani and G. MieliVergani, 2013. Autoimmune hepatitis: Contrasts and comparisons in children and adults-a comprehensive review. J. Autoimmunity, 46: 7160. DOI: $10.1016 /$ j.jaut.2013.08.004

Gaddi, E., S. Laucella, J. Balbaryski, C. Cantisano and V. Giraudi et al., 2000. Prognostic value of soluble intercellular adhesion molecule-1 (sICAM-1) in HIV-infected children. Scandinavian J. Immunol., 52: 628-33. DOI: 10.1111/j.13653083.2000.00820.x

González, C.M., F.J. López-Longo, J. Samson, I. Monteagudo and L. Carreño et al., 1998. Antiribonucleoprotein antibodies in children with HIV infection: A comparative study with childhood-onset systemic lupus erythematosus. AIDS Patient Care STDS, 12: 21-8. DOI: 10.1089/apc.1998.12.21

Gonzalez, J., O. Fay, M.C. Canero-Velasco, E. Fernandez and E. Cisaruk et al., 1997. Hepatitis a virus infection in children in Argentina: A pilot study. Acta Gastroenterol. Latinoamericana, 27: 331-334. PMID: 9460514.

Gutierrez, A., V. Chinchilla, A. Espasa and M. PerezMateo, 1996. Transient positivity of antinuclear and anti-smooth muscle antibodies in hepatitis a virus infection. J. Hepatol., 24: 123-128. DOI: $10.1016 / \mathrm{S} 0168-8278(96) 80197-8$

Habegger de Sorrentino, A., P. Motta, E. Iliovich and A. P. Sorrentino, 1997. Anti-Neutrophil Cytoplasmic Antibodies (ANCA) in patients with symptomatic and asymptomatic HIV infection. Med. B. Aires, 57: 294-298. PMID: 9640762.

Holborow, E.J., G.D. Johnson, L.J. Farrow, A.J. Zuckerman and P.E. Taylor et al., 1971. Immunofluorescent detection of autoantibodies in the sera of acute infective hepatitis patients. Ann. N. Y. Acad. Sci., 177: 214-217. DOI: 10.1111/j.1749-6632.1971.tb35049.x

Hu, N., J. Westra, M.G. Huitema, M. Bijl and C.G. Kallenberg et al., 2009. Coexpression of CD177 and membrane proteinase 3 on neutrophils in antineutrophil cytoplasmic autoantibodyassociated systemic vasculitis: Anti-proteinase 3mediated neutrophil activation is independent of the role of CD177-expressing neutrophils. Arthritis Rheumatism, 60: 1548-1557. DOI: 10.1002/art.24442
Huppertz, H.I., U. Triechel, A.M. Gassel, R. Jeschke and K.H. Meyer zum Büschenfelde, 1995. Autoimmune hepatitis following hepatitis a virus infection. J. Hepatol., 23: 204-208. DOI: 10.1016/0168-8278(95)80336-X

Ilan, Y., M. Hillman, R. Oren, A. Zlotogorski and D. Shouval, 1990. Vasculitis and cryoglobulinemia associated with persisting cholestatic hepatitis a virus infection. Am. J. Gastroenterol., 85: 586591. PMID: 2337062.

Iordache, L., O. Launay, O. Bouchaud, V. Jeantils and O. Fain et al., 2014. Autoimmune diseases in HIV-infected patients: 52 cases and literature review. Autoimmunity Rev., 13: 850-857. DOI: 10.1016/j.autrev.2014.04.005.

Jarvis, J.N., H. Taylor, M. Iobidze, J. Dejonge and F. Cohen et al., 1993. Rheumatoid factor expression and complement activation in children congenitally infected with human immunodeficiency virus. Clin. Immunol. Immunopathol., 67: 50-54. DOI: 10.1006/clin.1993.1044

Kamat, A., P. Ancuta, R.S. Blumberg and D. Gabuzda, 2010. Serological Markers for Inflammatory Bowel Disease in AIDS Patients with Evidence of Microbial Translocation. PLoS One, 5: 15533-15533. DOI: 10.1371/journal.pone.0015533

Karali, Z., S.T. Basaranoglu, Y. Karali, B. Oral and S.S. Kilic, 2011. Autoimmunity and hepatitis a vaccine in children. J. Investigat. Allergol. Clin. Immunol., 21: 389-393. PMID: 21905502.

Klaassen, R.J., R. Goldschmeding, K.M. Dolman, A.B. Vlekke and A.E. Von Dem Borne et al., 1992. Anti-neutrophil cytoplasmic autoantibodies in patients with symptomatic HIV infection. Clin. Exp. Immunol., 87: 24-30. PMID: 1733634.

Liberal, R., G. Mieli-Vergani and D. Vergani, 2013. Clinical significance of autoantibodies in autoimmune hepatitis. J. Autoimmun., 46: 17-24. DOI: 10.1016/j.jaut.2013.08.001

Manangeeswaran, M., J. Jacques, C. Tami, K. Konduru and G.G. Kaplan et al., 2012. Binding of Hepatitis a virus to its cellular receptor 1 inhibits T-regulatory cell functions in humans. Gastroenterology, 142: 1516-1525. DOI: 10.1053/j.gastro.2012.02.039 
Martínez-Rojano, H., H.E. Juárez, D.G. Ladrón and M.D.C. Gorbea-Robles, 2001. Rheumatologic manifestations of pediatric HIV infection. AIDS Patient Care STDS, 15: 519-526. DOI: 10.1089/108729101753205685

Matsuo, I., N. Ikuno, K. Omagari, H. Kinoshita and I.R. Mackay et al., 2000. Autoimmune reactivity of sera to hepatocyte plasma membrane in type 1 autoimmune hepatitis. J. Gastroenterol., 35: 226234. DOI: $10.1007 / \mathrm{s} 005350050335$

Moon, H.W., J.K. Noh, M. Hur, Y.M. Yun and S.Y. Kwon et al., 2009. High prevalence of autoantibodies in hepatitis a infection: The impact on laboratory profiles. J. Clin. Pathol., 62: 786788. DOI: $10.1136 /$ jcp.2009.064410

Muñoz Bertrán, E., V.R. Salazar, F.H. Robles, J.A.C. Estañ and E.M. Ramírez et al., 2002. Autoimmune hepatitis caused by acute hepatitis due to hepatitis a virus. Gastroenterol. Y Hepatol., 25: 501-504. PMID: 12361532.

Nguyen, B.Y. and J.D. Reveille, 2009. Rheumatic manifestations associated with HIV in the highly active antiretroviral therapy era. Current Opin. Rheumatol., 21: 404-10. DOI: 10.1097/BOR.0b013e32832c9d04

Nikolova, M., M. Liubomirova, A. Iliev, R. Krasteva and I.D. Vlahov et al., 2002. Clinical significance of antinuclear antibodies, antineutrophil cytoplasmic antibodies and anticardiolipin antibodies in heroin abusers. Israel Med. Associat. J., 4: 908-910. PMID: 12455177.

Nolan, S.L., N. Kalia, G.B. Nash, D. Kamel and C.O. Savage et al., 2008. Mechanisms of ANCAmediated leukocyte-endothelial cell interactions in vivo. J. Am. Society Nephrol., 19: 973-84. DOI: 10.1681/ASN.2007111166

Pando, M., J. Larriba, G.C. Fernandez, H. Fainboim and L. Fainboim et al., 1999. Pediatric and adult forms of type I autoimmune hepatitis in Argentina: Evidence for differential genetic predisposition. Hepatology, 20: 1374-1380. DOI: 10.1002/hep.510300611

Perrella, A., L. Vitiello, L. Atripaldi, C. Sbreglia and O. Perrella et al., 2008. Impaired function of CD4+/CD25+ $\mathrm{T}$ regulatory lymphocytes characterizes the self-limited hepatitis a virus infection. J. Gastroenterol. Hepatol., 23: 105-110. DOI: $10.1111 / \mathrm{j} .1440-1746.2007 .05008 . x$
Perumalswami, P., L. Peng and J.A. Odin, 2009. Vaccination as a triggering event for autoimmune hepatitis. Seminars Liver Dis., 29: 331-334. DOI: 10.1055/s-0029-1233537

Rodriguez, C., E.R. Stiehm and S. Plaeger-Marshall, 1993. Peripheral B-cell activation and immaturity in HIV-infected children. Annals N. Y. Acad. Sci., 693: 291-294. DOI: 10.1111/j.17496632.1993.tb26287.x

Rodríguez-Mahou, M., J. López-Longo, N. Lapointe, L. Carreño and E. Fernández-Cruz et al., 1994. Autoimmune phenomena in children with human immunodeficiency virus infection and acquired immunodeficiency syndrome. Acta Paediatr. Supplement, 400: 31-34. DOI: 10.1111/j.16512227.1994.tb13331.x

Roessler, V.P., 2007. Manifestaciones Reumatológicas en Pacientes con Síndrome de Inmunodeficiencia Adquirida (VIH/SIDA). Reumatología, 23: 151-155.

Savige, J.A., L. Chang, S. Horn and S.M. Crowe, 1994. Anti-nuclear, anti-neutrophil cytoplasmic and antiglomerular basement membrane antibodies in hivinfected individuals. Autoimmunity, 18: 205-211. DOI: $10.3109 / 08916939409007997$

Schreiber, A., H. Xiao, J.C. Jennette, W. Schneider and R. Kettritz et al., 2009. C5a receptor mediates neutrophil activation and ANCA-induced glomerulonephritis. J. Am. Society Nephrol., 20: 289-98. DOI: 10.1681/ASN.2008050497

Schuval, S.J., V.R. Bonagura and N.T. Ilowite, 2001. Rheumatologic manifestations of pediatric HIV infection. J. Rheumatol., 20: 1578-82. DOI: 10.1089/108729101753205685

Segev, A., R. Hadari, T. Zehavi, M. Schneider and Y.A. Mekori et al., 2001. Lupus-like syndrome with submassive hepatic necrosis associated with hepatitis a. J. Gastroenterol. Hepatol., 16: 112-114. DOI: 10.1046/j.1440-1746.2001.02314.X

Seok, Y.S., K.G. Lee, E.S. Jung, H. An and H.S. Ryu et al., 2011. Clinical significance of the detection of antinuclear antibodies in patients with acute hepatitis a. Gut Liver, 5: 340-347. DOI: 10.5009/gnl.2011.5.3.340

Singh, G., S. Palaniappan, O. Rotimi and P.J. Hamlin, 2007. Autoimmune hepatitis triggered by hepatitis a. Gut, 56: 304-304. DOI: 10.1136/gut.2006.111864

Skoog, S.M., R.E. Rivard, K.P. Batts and C.I. Smith, 2002. Autoimmune hepatitis preceded by acute hepatitis a infection. Am. J. Gastroenterol., 97: 1568-1569. DOI: $\quad 10.1111 /$ j.15720241.2002.05751.x 
Stricker, K., E. Knipping, T. Böhler, A. Benner and K.M. Debatin et al., 1998. Anti-CD95 (APO-1/Fas) autoantibodies and $\mathrm{T}$ cell depletion in Human Immunodeficiency Virus type 1 (HIV-1)-infected children. Cell Death Differentiat., 5: 222-230. DOI: 10.1038/sj.cdd.4400332

Tabor, E., 1987. Guillain-barré syndrome and other neurologic syndromes in hepatitis A, B and non-A, non-B. J. Med. Virol., 21: 207-212. DOI: 10.1002/jmv. 1890210303

Vento, S., B.M. McFarlane, C.G. McSorley, S. Ranieri and I.G. McFarlane et al., 1988. Liver autoreactivity in acute virus A, B and non-A, nonB hepatitis. J. Clin. Laboratory Immunol., 25: 1-7. PMID: 3133482.

Vento, S., T. Garofano, G. Di Perri, L. Dolci and D. Bassetti et al., 1991. Identification of hepatitis a virus as a trigger for autoimmune chronic hepatitis type 1 in susceptible individuals. Lancet, 337: 1183-1187. DOI: 10.1016/0140-6736(91)92858-Y

Vergani, D. and G. Mieli-Vergani, 2008. Autoimmune Hepatitis. Textbook Hepatol. Basic Sci. Clin. Practice, 1: 1089-10101. DOI: 10.1002/9780470691861.ch11b

Zandman-Goddard, G. and Y. Shoenfeld, 2002. HIV and autoimmunity. Autoimmunity Rev., 1: 329-337. DOI: $10.1016 /$ S1568-9972(02)00086-1

\section{LIST OF ABBREVIATIONS}

ANA: Anti-nuclear antibodies AMA: Anti-mitochondrial antibodies SMA: Anti-smooth muscle antibodies APC: Anti-parietal cells antibodies LKM: Anti-liver-kidney-microsomal antibodies DNAds: Anti-double strand DNA antibodies ATG: Anti-tyroglobulin antibodies RF: Rheumatoid factor ANCA: Anti-neutrophil cytoplasmic antibodies ANCA-PR3: ANCA proteinase-3 ANCA-MPO: ANCA myeloperoxidase HAV: Hepatitis A virus HIV: Human Immunodeficiency Virus AIH: Autoimmune hepatitis HBV: Hepatitis B virus HCV: Hepatitis C virus HTLV-1: Human T-lymphotropic virus 1 AST/SGOT: Aspartate transaminase/Glutamic oxaloacetic transaminase

ALT/SGPT: Alanine transaminase/Glutamic-pyruvic transaminase

AAV: ANCA-associated vasculitis

HAVCR1: Hepatitis A virus cellular receptor 1

TGF- $\beta$ : Transforming growth factor- $\beta$ 